\title{
Habitat and behaviour of adult yellowfin tuna (Thunnus albacares) in the waters off southwestern Taiwan determined by pop-up satellite archival tags
}

\author{
Jinn-Shing Weng ${ }^{1}$, Ming-An Lee ${ }^{2}$, Kwang-Ming Liu ${ }^{3, *}$, Hsing-Han Huang ${ }^{1}$ and Long-Jing $\mathrm{Wu}^{1}$ \\ ${ }^{1}$ Coastal and Offshore Resources Research Center, Fisheries Research Institute Council of Agriculture, Executive Yuan, \\ Kaohsiung 80627, Taiwan \\ ${ }^{2}$ Department of Environmental Biology and Fisheries Science, National Taiwan Ocean University, Keelung 20224, Taiwan \\ ${ }^{3}$ Institute of Marine Affairs and Resource Management, National Taiwan Ocean University, Keelung 20224, Taiwan
}

Received 9 April 2017 / Accepted 21 August 2017

Handling Editor: David Kaplan

\begin{abstract}
Yellowfin tuna(Thunnus albacares) is an economically important species for longline and trolling fisheries in the waters off the southwestern coast of Taiwan, yet this species' movement patterns remain poorly understood. This study provides the first information on the movement and behaviour of adult yellowfin tuna using pop-up satellite archival tags in the waters off the southwestern coast of Taiwan. In total, 11 tuna (ranging from 116 to $135 \mathrm{~cm}$ in fork length) were tagged and released from 2011 to 2013. Seven fish were successfully tracked to provide information on depth and temperature preferences as well as horizontal movements. The majority of the vertical movements $(30.3 \%)$ of yellowfin tuna occurred in the $50-\mathrm{m}$ depth range in mixed layers. The mean swimming depth was $74.4 \mathrm{~m}( \pm 50.7 \mathrm{~m})$ during the daytime and $94 \mathrm{~m}( \pm 72.5 \mathrm{~m})$ at nighttime, which was a contrast to the findings in other waters. The maximum diving depth was $1000 \mathrm{~m}$, where the water temperature was approximately $4{ }^{\circ} \mathrm{C}$. This value was similar to the measurements made by a CTD near a depth of $1000 \mathrm{~m}$, where the water temperature was approximately $4.2^{\circ} \mathrm{C}$ and the $\mathrm{O}_{2}$ level was $3.0 \mathrm{mg} 1^{-1}$. One of the tuna travelled $190 \mathrm{NM}$ (straight distance) in 37 days, with most of its horizontal movements $(70.6 \%)$ occurring at temperatures that ranged from 26 to $28^{\circ} \mathrm{C}$, suggesting that yellowfin tuna have a preference for this temperature range throughout the period of PAST observation.
\end{abstract}

Keywords: Pop-up satellite archival tag / Habitat / Vertical movement / Horizontal movement

\section{Introduction}

Understanding the biology of marine animals requires knowledge of where they live and their movement behaviours in different habitats (Turchin, 1998). The distribution and movement of highly migratory tunas are influenced by environmental factors (Lehodey et al., 1998). Spatial-temporal heterogeneity in the marine environment is believed to greatly affect the biology and availability of tuna stocks, as well as their vulnerability to different fishing techniques, thus resulting in variability in nominal catch rates. Sea temperature is one of the most important physical factors because it modifies the geographical and vertical aggregation patterns of tuna through its effect on feeding, reproduction, and movement behaviour and thermoregulation (Fonteneau, 1998).

\footnotetext{
*Corresponding author: kmliu@mail.ntou.edu.tw
}

Ultrasonic tags have been used to track fish movement behaviour since 1950s (Arnold and Dewar, 2001) but these tags can only be applied to track fish in short time period (Yuen, 1970). On the other hand, archival tags, which were developed in the early 1990s, can be applied to measure and store large quantities of depth and temperature data collected over extended periods (Arnold and Dewar, 2001). Although implanted archival tags can record fine scale data for long periods of time, one limitation of archival tags is that the stored data can be retrieved only if the tagged fish is recaptured. As the recovery rates of tagged fish was very low, we decided to use pop-up satellite archival tag (PSAT) technology in this study. These types of tagging study can be expensive but offer the most cost-effective way of obtaining the pertinent data from small to moderate sample sizes. The PSATs can be programmed to measure and record depth (pressure) and ambient water temperature as well as the solar irradiance for 
estimating geographic location (Hoolihan et al., 2011). These features have advanced the research scope and are not limited to pelagic fish movements and habitat but can also measure the post-release survival for tuna (Block et al., 1998). The PSATs have limitations on locating the position in a fine-scale environment as the light-based geolocation methods provide only broad scale information on horizontal movements.

In recent years, many researchers have used PSATs to study the relationship between tuna and oceanographic conditions (Arnold and Dewar, 2001; Brill and Lutcavage, 2001; Gunn and Block, 2001). For example, Wilson et al. (2005) and Lam et al. (2014) used PSATs to examine the movements of bluefin and bigeye tuna associated with different oceanographic conditions in the Northwest Atlantic. Weng et al. (2009) examined the habitat and behaviour of yellowfin tuna in the Gulf of Mexico using PSATs. Except sailfish (Chiang et al., 2011) and whale shark (Hsu et al., unpublished data), PSAT technique has not previously been used to study the behaviour of tunas in Taiwanese waters.

Yellowfin tuna (Thunnus albacares) is capable of extended movements, is distributed worldwide in tropical and subtropical waters (Collette and Nauen, 1983) and is a crucial target species for purse seine and longline fisheries in the Pacific Ocean. The global catch of this species exceeds 1.2 million MT, 570000 MT of which was from the Western and Central Pacific Ocean in 2015 (WCPFC Year Book, 2015). Tagging experiments with plastic dart tags on yellowfin tuna have been conducted since the early 1950s throughout the Eastern Pacific Ocean (EPO). Fink and Bayliff (1970) and Bayliff (1984) documented that the horizontal movements of yellowfin tuna were mostly restricted to less than $1852 \mathrm{~km}$. Because plastic dart tags cannot record the complete movement tracks of fish, many researchers have used archival tags to study the movements and behaviours of tuna instead (Brill et al., 1999; Musyl et al., 2003). Archival tags have greatly enhanced our understanding of the movement, behaviour, and habitat of yellowfin tuna (Arnold and Dewar, 2001; Gunn and Block, 2001).

That oxygen concentration is a notable limiting factor for all fish has been observed although a wide range of tolerances to hypoxic conditions across species (Brill, 1994). Cayre and Marsac (1993) noted that yellowfin tuna rarely move into waters with oxygen lower than $5.7 \mathrm{mgl}^{-1}$. In laboratory studies, yellowfin tuna have shown initial physiological responses to low oxygen content ranging from 5.1 to $6.1 \mathrm{mg} \mathrm{l}^{-1}$ (Bushnell et al., 1990). Both Cayre and Marsac (1993) and Block et al. (1997) have also indicated that yellowfin tuna can only stay in cold waters or oxygen-deficient environments for a few minutes. These results are helpful for explaining the vertical movement behaviour of yellowfin tuna, such as their deep diving behaviour (Holland et al., 1990). On rare occasions, yellowfin tuna have been found to make dive to excess of $1000 \mathrm{~m}$ and waters cooler than $5^{\circ} \mathrm{C}$ (Dagorn et al., 2006; Schaefer et al., 2007).

The yellowfin tuna were captured by longline, trolling line, handline, and tiger net fisheries near the surface fish aggregating devices (FADs) in the waters off southwestern Taiwan from September to November. According to local fishermen's experience, adult yellowfin tuna migrate from the South China Sea to the waters off southwestern Taiwan during the same period. The feeding behaviour of juvenile yellowfin tuna around subsurface FADs in the waters off southwestern

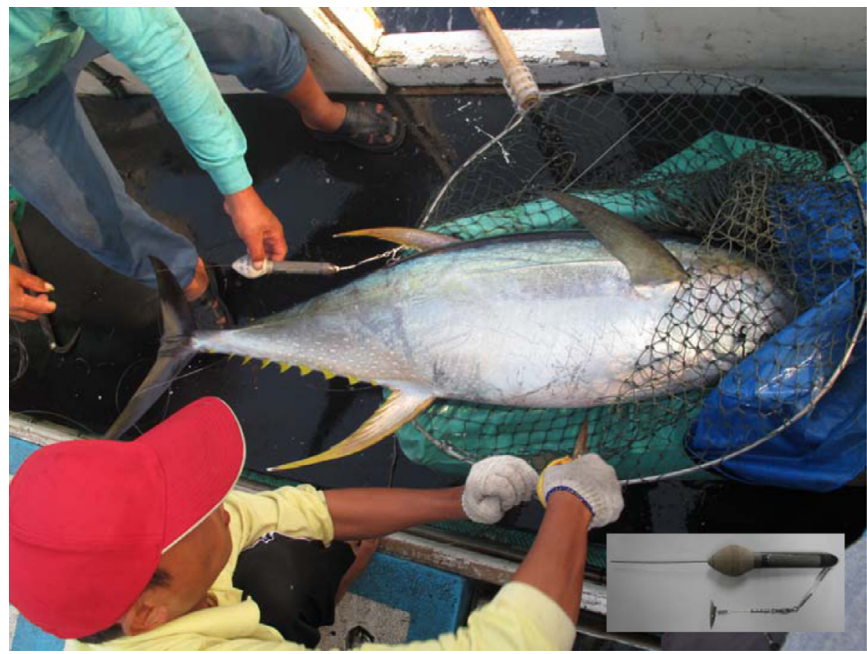

Fig. 1. Picture of a yellowfin tuna (cm FL) equipped with the pop-up satellite archival tag (MK-10) before release.

Taiwan has been documented (Weng et al., 2013, 2015). The authors found that juvenile yellowfin tuna aggregated at a depth of $60-80 \mathrm{~m}$ in the daytime and at a depth of $40 \mathrm{~m}$ at nighttime, and fish stayed near the subsurface FADs for up to 31 days. Kleiber and Hampton (1994) and Itano and Holland (2000) documented that FAD arrays may have influenced movement parameters of yellowfin. As the movement patterns of adult yellowfin tuna in the waters off Taiwan are still unknown, the objective of this study was to examine the movement and behaviour of adult yellowfin tuna in the waters off southwestern Taiwan using PSATs.

\section{Material and methods}

The yellowfin tuna specimens used in this study were caught by a handline fishing vessel near the subsurface FADs in the waters off the southwestern coast of Taiwan $\left(21^{\circ} 46^{\prime}\right.$ $22^{\circ} 46^{\prime} 0 \mathrm{~N} ; 118^{\circ} 57^{\prime} 0-120^{\circ} 15^{\prime} \mathrm{E}$ ) from September 2011 to August 2013. In addition to yellowfin tuna, bigeye, skipjack tuna, dolphin fish, and marlins were caught by this fishery and the yellowfin tuna accounted for $70 \%$ of the total catch. The fishermen catch juvenile yellowfin tuna and skipjack as live baits to catch large tuna. The yellowfin tuna were and pulled onto the deck, and their eyes were covered with a damp cloth. Tags were attached to stainless steel darts with nylon monofilament line $(1.4 \mathrm{~mm}$ diameter $\times 15 \mathrm{~cm})$ and stainless steel crimps matching the diameter of the line. The dart was embedded in the muscle near the second dorsal fin (Fig. 1), there was not attempt to pass the tag dart head through the pterygiophores of the dorsal fin. The wound was coated with antibiotic ointment, and the measurement on fork length was taken. When the tagged yellowfin tuna were released, the time and location were recorded based on the Global Positioning System of the fishing vessel.

We deployed eleven model MK-10 PSATs (Wildlife Computers, Redmond, WA, USA). The temperature $\left({ }^{\circ} \mathrm{C}\right)$ data were binned into the following 13 intervals: $0-6,6-10,10-12$, 12-14, 14-16, 16-18, 18-20, 20-22, 22-24, 24-26, 26-28, 2830 , and $>30^{\circ} \mathrm{C}$, and the depth $(\mathrm{m})$ data bins were $0-15,15-30$, $30-50,50-75,75-100,100-130,130-160,160-200,200-250$, 
Table 1. Summary of 11 yellowfin tuna tracked by using pop-up satellite archival tags from 2011 to 2013.

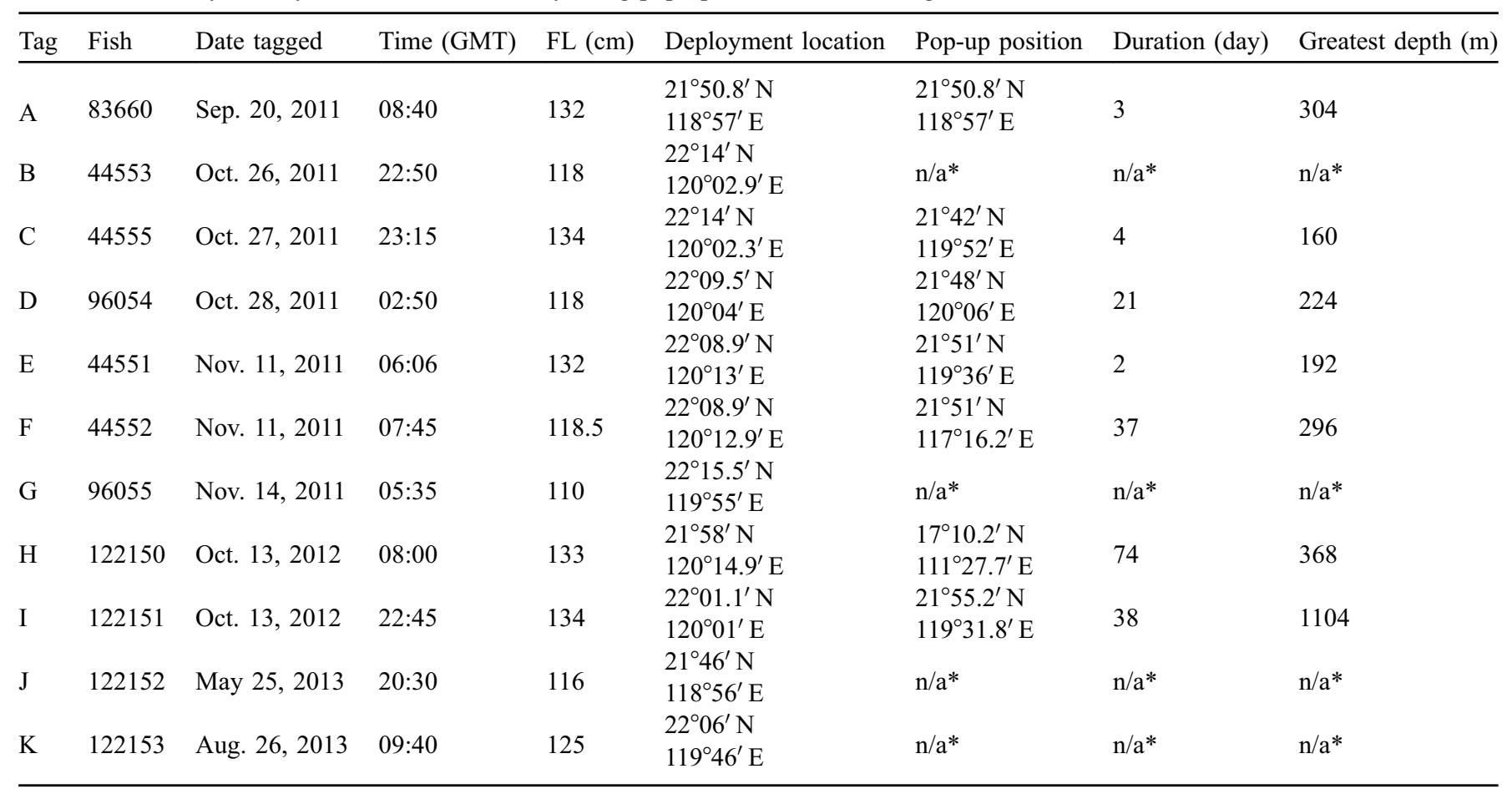

n/a*: data are not available.

250-300, 300-400, 400-500, and $>500 \mathrm{~m}$. The water depth and temperature were recorded every minute and the data were summarized into successive six-hour intervals beginning at 00:00 h (GMT). The pop-up time was set to 180 days after deployment. The fish bearing tags $\mathrm{C}$ and I remained in the same water layer for 3 days with depth over 1500 m, RD 1800 device automatically severed, and PSATs floated to the surface. The PSATs recorded the movements information of the tagged fish, including maximum and minimum depths to which they travelled and the temperature of the waters in which they swam. The PSATs provided accurate end locations for where tags were popped off based on the Doppler shifts of successive transmissions during a single satellite pass. The daily geographic location of tagged fish was estimated using a WC-AMP (Wildlife Computers, Redmond, WA, USA) from the light level data. Light-based geolocation methods are often rendered difficult due to the behaviour of tagged animals. For instance, fish spend substantial time at great depth where light intensity is near the threshold of sensitivity for most electronic tags prior to sunrise and sunset (Musyl et al., 2003). We applied a sea surface temperature (SST) corrected unscented Kalman filter (Lam et al., 2008) to obtained most probable tracks. We also calculated cumulative percentage of temperature readings from pop-up tags attached to yellowfin tunas that expressed as differences from daily mean SST to confirm the distinct diel pattern and temperature preference of these fish. Depth excursions were limited to a temperature changes of $\leq 8^{\circ} \mathrm{C}$ (Chiang et al., 2011). Finally, the maximum horizontal movement distance of the yellowfin tuna was estimated, and depth and temperature data from daytime and nighttime periods were recorded.

Subsequently, a paired Mann-Whitney $U$ test was used to compare mean vertical movement depths between daytime and nighttime periods based on the depth data recorded by the PSATs. A conductivity-temperature-depth array with an oxygen gauge was used to measure the water temperature, depth, and $\mathrm{O}_{2}$ at the release site $\left(22^{\circ} 12^{\prime} \mathrm{N} ; 119^{\circ} 36.2^{\prime} \mathrm{E}\right)$ off southwestern Taiwan. The relationship between horizontal movement behaviour and temperature changes in the environment was analyzed based on position image data from the Department of Environmental Biology and Fisheries Science at National Taiwan Ocean University from a high-resolution radiometer (AVHRR; National Oceanic and Atmospheric Administration/Advanced Very High Resolution Radiometer) and National Oceanic and Atmospheric Administration satellite sensor data.

\section{Results}

\subsection{Vertical movements}

In total, 11 yellowfin tuna ranging from 110 to $134 \mathrm{~cm} \mathrm{FL}$ were tagged with PSATs in the waters off southwestern Taiwan between 2011 and 2013 (Tab. 1, Fig. 2). No tags achieved programmed pop off dates in this study. Four tagged fish were failed to transmit signal and seven tagged fish were successfully tracked for 2-74 days. Among them, the fish bearing tag $\mathrm{H}$ was tracked for 74 days, the final position was in the South China Sea $\left(17^{\circ} 10.2^{\prime} \mathrm{N} ; 111^{\circ} 27.7^{\prime} \mathrm{E}\right)$ with a straightline distance of approximately 590 NM from Taiwan (Fig. 2). However, this tagged fish did not provide data from 16 October to 12 November, and 28 November to 6 December 2012, respectively. Three fish were tracked for 20-40 days, the other three were tracked for only 2-4 days, and four fish bearing with tags were failed (Tab. 1). Six yellowfin tuna moved from the southwestern waters of Taiwan and then lingered in the waters 


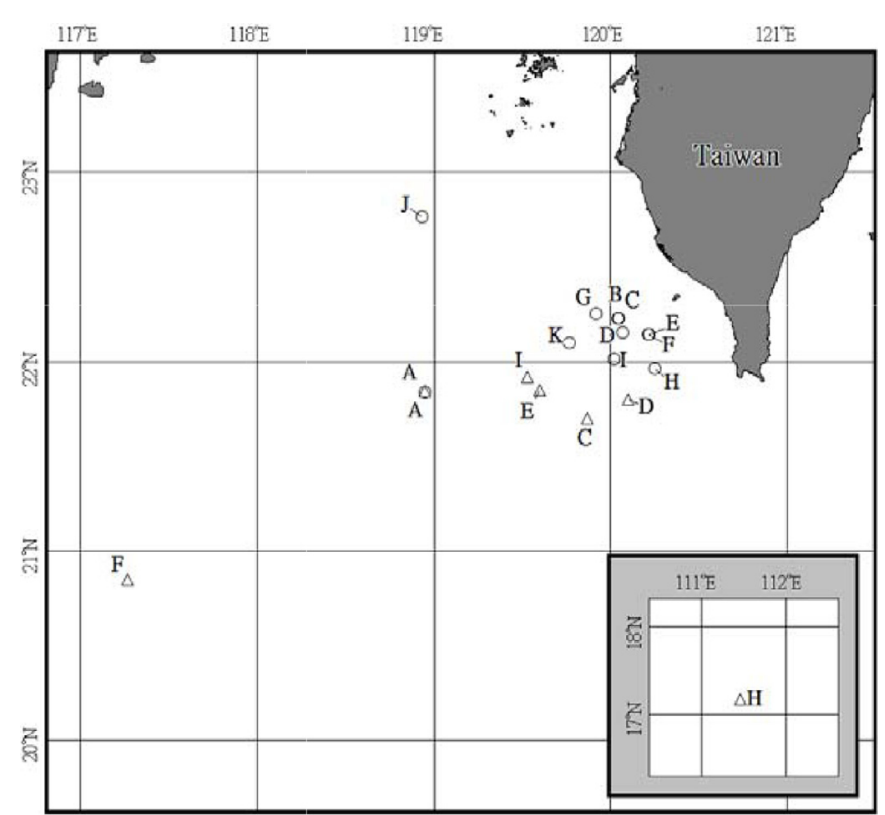

Fig. 2. Deployment and pop-up positions of 11 yellowfin tuna (labeled from A to K) tagged with satellite archival tags in the waters off southwestern Taiwan from 2011 to 2013. O: Deployment locations, $\triangle$ : pop-up endpoint positions.

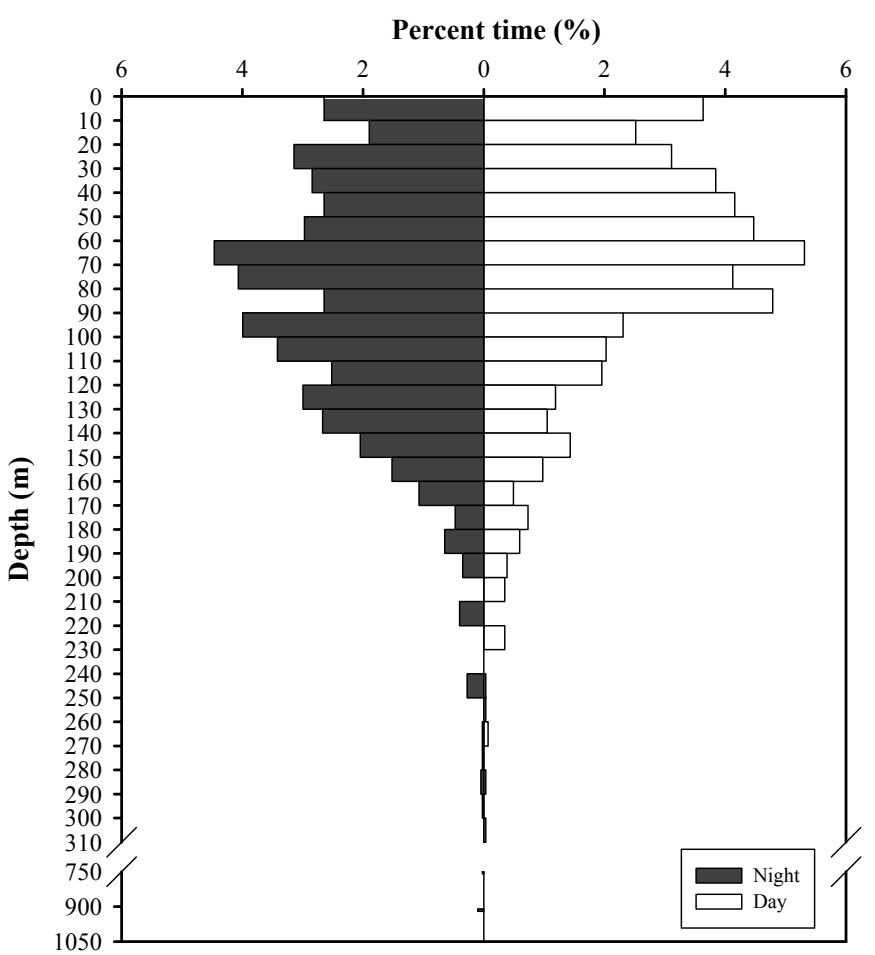

Fig. 3. Percentage of time spent in different depth for 7 tagged yellowfin tuna in a total of 189 days. $\square$ : Nighttime and $\square$ : daytime.

near Taiwan (Fig. 2, Tab. 1). The depth occupied by the tuna was primarily $(97.6 \%)$ within a depth of $200 \mathrm{~m}$ of the surface during this period; deep diving behaviour (exceeding a depth of $200 \mathrm{~m}$ ) accounted for only $1.14 \%$ of vertical movement (notably, however, some of the fish exceeded a depth of $1000 \mathrm{~m}$ ). Moreover, the yellowfin tuna occupied depths less

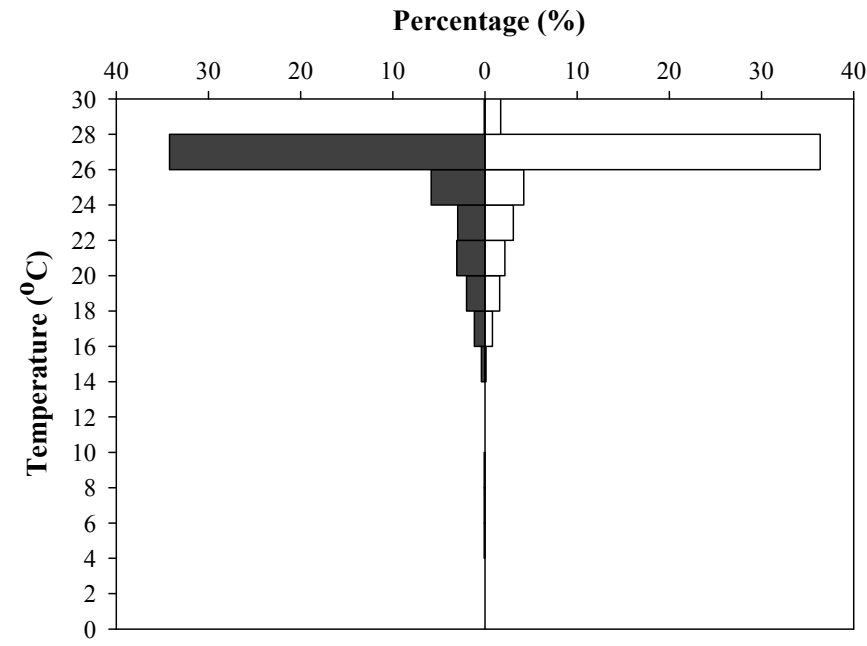

Fig. 4. Percentage of time spent in different temperature for 7 tagged yellowfin tuna in a total of 189 days. $\square$ : Nighttime and $\square$ : daytime.

than $50 \mathrm{~m}(34.6 \%$ and $26.3 \%$ in the nighttime and daytime periods, respectively) (Fig. 3). The mean swimming depth of the tuna was $74.0 \mathrm{~m}( \pm 48.8 \mathrm{~m})$ during the daytime and $93 \mathrm{~m}$ $( \pm 71.3 \mathrm{~m})$ during the nighttime. Significant differences in mean depth between daytime and nighttime were found based on the $U$ test results $(p<0.05)$.

\subsection{Horizontal movements}

For horizontal movement, most yellowfin tuna (70.6\%) stayed in waters that SSTs were $26-28^{\circ} \mathrm{C}$ throughout the period of PSAT observations. Yellowfin tuna can dive to deep waters where the minimum temperature is $4^{\circ} \mathrm{C}$ (Fig. 4). In this study, NOAA satellite data showed the SST surrounding Taiwan ranged from 26 to $28^{\circ} \mathrm{C}$ in November, 2011 and 2012 (Fig. 5). The three fish that stayed in the southwestern Taiwan waters for the longest period were those bearing tags D (21 days), F (37 days), and I (38 days).

The total horizontal distance of movement was approximately $75 \mathrm{NM}$ for the fish bearing tag D (Fig. 5a) and its maximum vertical movement from surface waters to $224 \mathrm{~m}$ during the daytime and $216 \mathrm{~m}$ during the nighttime (Fig. 6a). The mean vertical movement was $102.8 \mathrm{~m}( \pm 43.9 \mathrm{~m})$ during the daytime, and $103.4 \mathrm{~m}( \pm 42.6 \mathrm{~m})$ at nighttime. No significant difference in the mean depths of vertical movement between daytime and nighttime was found ( $U$ test, $p>0.05$; Tab. 2). During this 21-day period, the water temperature around this individual fish ranged from the surface (mostly closer to $28^{\circ} \mathrm{C}$ ) to $216 \mathrm{~m}$ in depth $\left(15.6^{\circ} \mathrm{C}\right)$ (Fig. 6b). The fish bearing tag $\mathrm{F}$ moved towards the waters off southeastern Taiwan, approximately $100 \mathrm{NM}$ away from the waters off southern Taiwan, and then moved westward for approximately $220 \mathrm{NM}$ over 37 days. When the satellite archival tag was pupoff, the straight movement was estimated to be approximately 190 NM from Taiwan (Fig. 5b). During this period, the maximum diving depth of the fish was $264 \mathrm{~m}$ during the daytime and $296 \mathrm{~m}$ at nighttime (Fig. 7a). The mean vertical movement depth was $75.3 \mathrm{~m}( \pm 56.8 \mathrm{~m})$ during the daytime and $75.3 \mathrm{~m}( \pm 57.9 \mathrm{~m})$ at nighttime. Thus, no significant difference in the mean depths of vertical movement between the daytime 


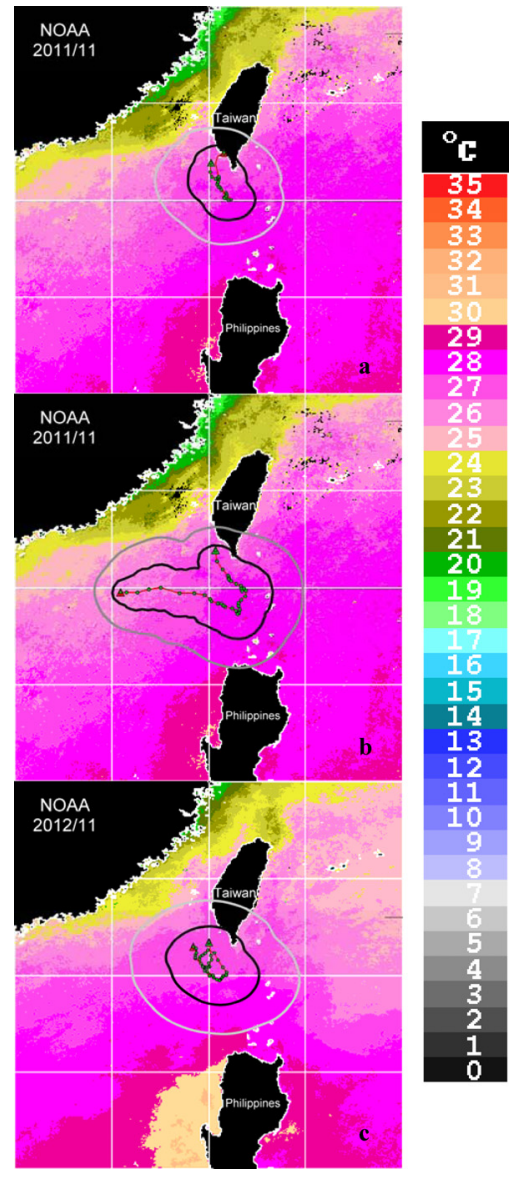

Fig. 5. Deployment locations ( $f x 1)$, pop-up endpoint positions ( $f \times 2)$ and movement routes of 3 yellowfin tuna with tags D (a), F (b), and I (c). The dark and light grey ellipses indicate the 50\% and $95 \%$ confidence intervals of trajectory route. The monthly satellite-derived SST images from NOAA/AVHRR shows the hydrotropic features in November 2011 (a), (b), and November 2012 (c).

and nighttime was noted ( $U$ test, $p>0.05$; Tab. 2 ). The water temperature around this individual fish ranged from 17.2 to $28^{\circ} \mathrm{C}$ (mostly closer to $27^{\circ} \mathrm{C}$ ) during this period (Fig. $7 \mathrm{~b}$ ).

The fish bearing tag I remained close to the waters off southwestern Taiwan for 38 days. The maximum diving depth of the fish was $287 \mathrm{~m}$ before day 30 . On the 31 st day the fish exhibited deep dive behaviour to a depth of $1000 \mathrm{~m}$, and died on day 38. The fish sank to $1900 \mathrm{~m}$, and the tag was pup-off and floated to the surface. Its straight-line horizontal movement was approximately $70 \mathrm{NM}$ (Fig. 7c). During this period, the maximum diving depth of the fish was $1104 \mathrm{~m}$ in the daytime and $1050 \mathrm{~m}$ in the nighttime (Fig. 8a). The average vertical movement depth was $72.3 \mathrm{~m}( \pm 48.6 \mathrm{~m})$ during the daytime and $91.2 \mathrm{~m}( \pm 53.5 \mathrm{~m})$ at nighttime. A significant difference in the mean vertical movement depth between daytime and nighttime was found ( $U$ test, $p<0.05$; Tab. 2). The water temperature around this individual fish ranged from 4 to $28.4{ }^{\circ} \mathrm{C}$ (mostly closer to $28^{\circ} \mathrm{C}$ ) during this period (Fig. 8b). It is apparent that 3 yellow tunas spent their majority time in certain temperature layer, and approximately $80 \%$ of the temperatures of occupied waters were within $4{ }^{\circ} \mathrm{C}$ of estimated SST (Tab. 3).
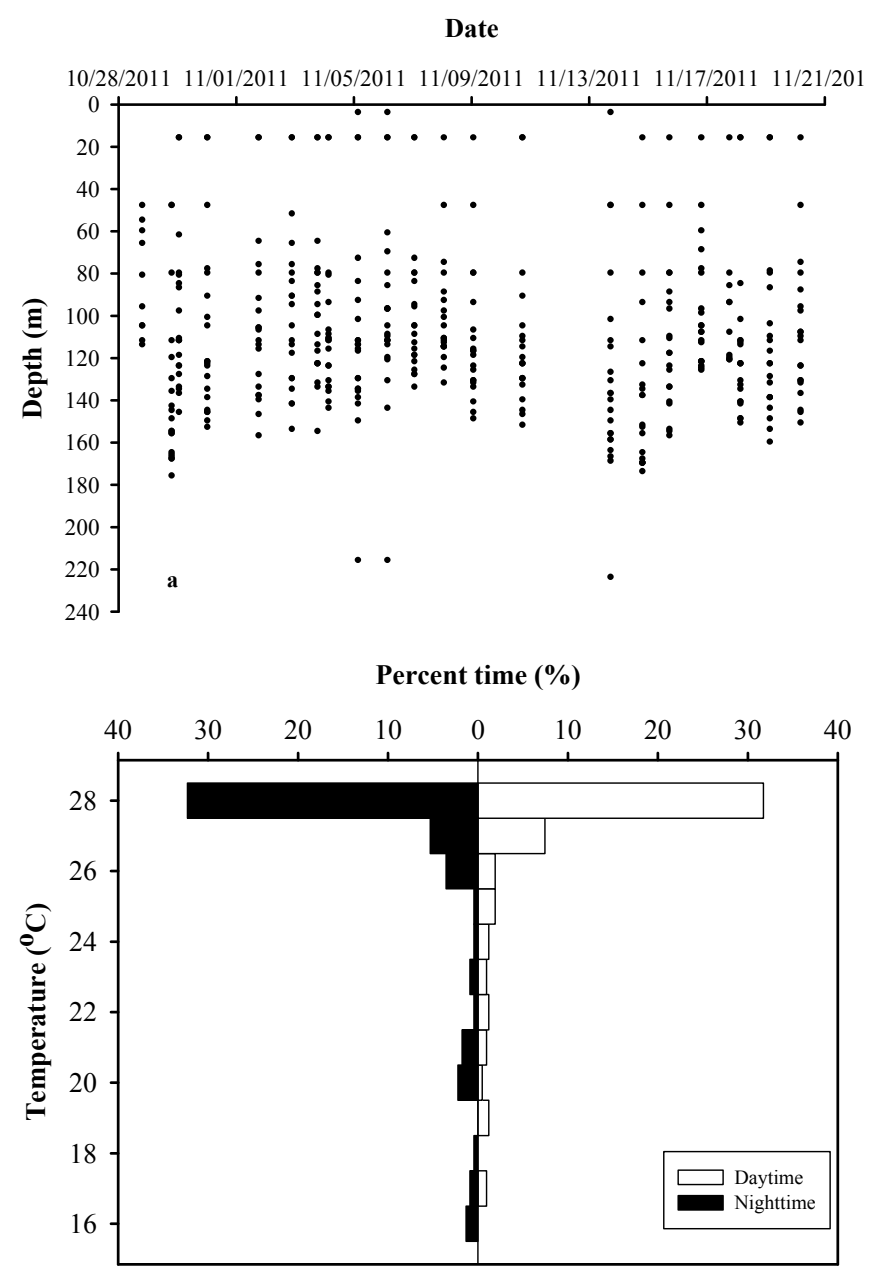

Fig. 6. Vertical movement distribution (a), and percentage of time spent at different temperature (b) for the fish bearing tag D.

\subsection{Temperature, depth, and $\mathrm{O}_{2}$ content in the southwestern waters of Taiwan}

The sea surface temperature recorded by the CTD was as high as $29.0^{\circ} \mathrm{C}$ in August, but dropped to $26.7^{\circ} \mathrm{C}, 23.3^{\circ} \mathrm{C}$, $16.4{ }^{\circ} \mathrm{C}, 12.9^{\circ} \mathrm{C}, 8.5^{\circ} \mathrm{C}$ and $6.5^{\circ} \mathrm{C}$; the $\mathrm{O}_{2}$ content levels have $6.2,6.4,5.6,5.0,4.6,3.7$ and $3.3 \mathrm{mg} \mathrm{l}^{-1}$ at water depths of 0 , 50, 100, 200, 300, and $\geq 500 \mathrm{~m}$ (Fig. 9a, Table 4), respectively. In May, the water temperature contents have 27.1, 27.2 ${ }^{\circ} \mathrm{C}, 24.1{ }^{\circ} \mathrm{C}, 15.2{ }^{\circ} \mathrm{C}, 12.4{ }^{\circ} \mathrm{C}, 8.1{ }^{\circ} \mathrm{C}$, and $4.2{ }^{\circ} \mathrm{C}$; the $\mathrm{O}_{2}$ content levels have $6.4,6.3,5.5,4.9,4.4,3.3$, and $3.1 \mathrm{mg} \mathrm{l}^{-}$ 1 at depths of $0,50,100,200,300,500$, and $\geq 1000 \mathrm{~m}$, respectively (Fig. 9b, Table 4). In November, the water temperature contents have $27.2,26.8^{\circ} \mathrm{C}, 22.7^{\circ} \mathrm{C}, 15.4^{\circ} \mathrm{C}$, $11.9{ }^{\circ} \mathrm{C}, 8.7^{\circ} \mathrm{C}$, and $4.4^{\circ} \mathrm{C}$; the $\mathrm{O}_{2}$ content levels have $6.4,6.4$, $4.9,4.5,4.2,3.4$ and $3.1 \mathrm{mg} \mathrm{l}^{-1}$ at depths of $0,50,100,200$, 300,500 , and $\geq 1000 \mathrm{~m}$, respectively (Fig. 9c, Table 4). The surface water had the highest levels of O2 $\left(6.2-6.4 \mathrm{mg} \mathrm{l}^{-1}\right)$, which varied slightly among seasons. In other words, the amount of $\mathrm{O} 2$ gradually decreased with the water depth (Fig. 9a-c, Table 4). 
Table 2. Comparison of the mean depth of the vertical movements of 3 yellowfin tuna in the daytime and nighttime.

\begin{tabular}{|c|c|c|c|c|c|c|c|c|c|}
\hline Tag & \multicolumn{4}{|c|}{ Day (m) } & \multicolumn{4}{|c|}{ Night (m) } & $p^{*}$ \\
\hline $\mathrm{D}$ & 231 & $102.8 \pm 43.9$ & 113 & $16-224$ & 242 & $103.4 \pm 42.6$ & 113 & $16-216$ & $>0.05$ \\
\hline $\mathrm{F}$ & 161 & $75.3 \pm 56.8$ & 64 & $8-296$ & 133 & $75.3 \pm 57.9$ & 64 & $8-296$ & $>0.05$ \\
\hline I & 965 & $72.3 \pm 58.8$ & 63.5 & $2.5-259$ & 1094 & $91.2 \pm 53.4$ & 87 & $0-287.5$ & $<0.05$ \\
\hline
\end{tabular}

$n$, number of depth readings.

*Mann-Whitney $U$-test.

Date

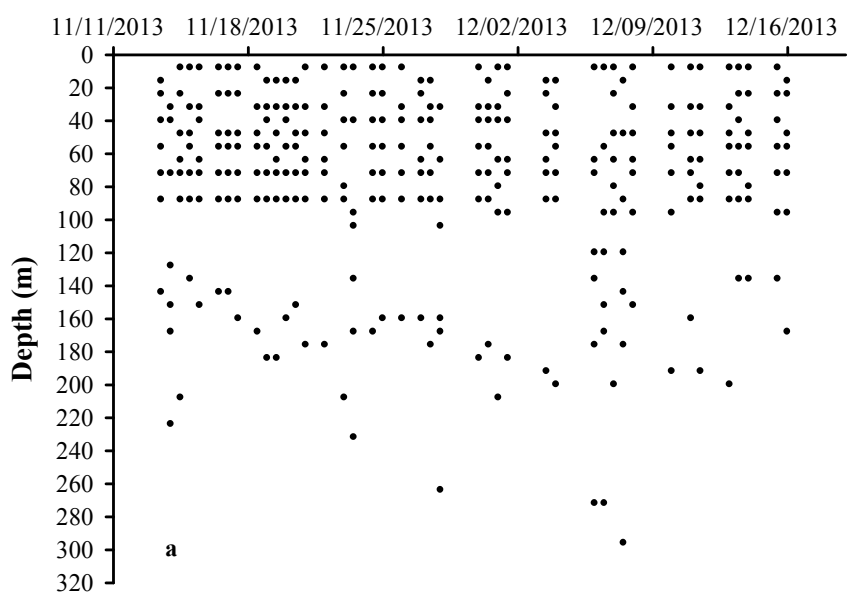

Percent time (\%)

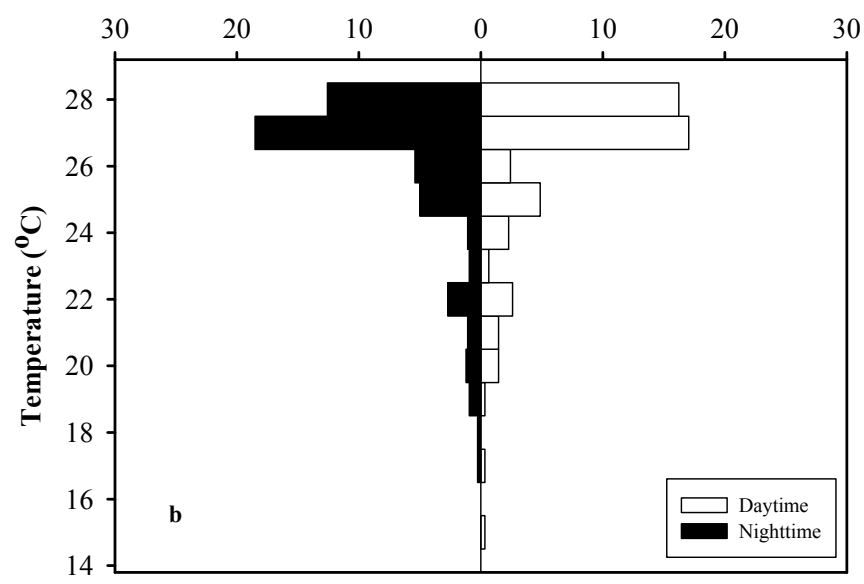

Fig. 7. Vertical movement distribution (a), and percentage of time spent at different temperature (b) for the fish bearing tag F.

\section{Discussion}

There are still many challenges in marine animal research regarding the performance of satellite archival tags (Hays et al., 2007). In particular, the early detachment of tags is a substantial problem (Arrizabalaga et al., 2008), with the vast majority of PSATs $(80 \%)$ being shed before their programmed pop-up date (Arnold and Dewar, 2001; Gunn and Block, 2001). However, the factors influencing the reporting rates of PSATs, intermittent data transmission to Argos, and the duration that
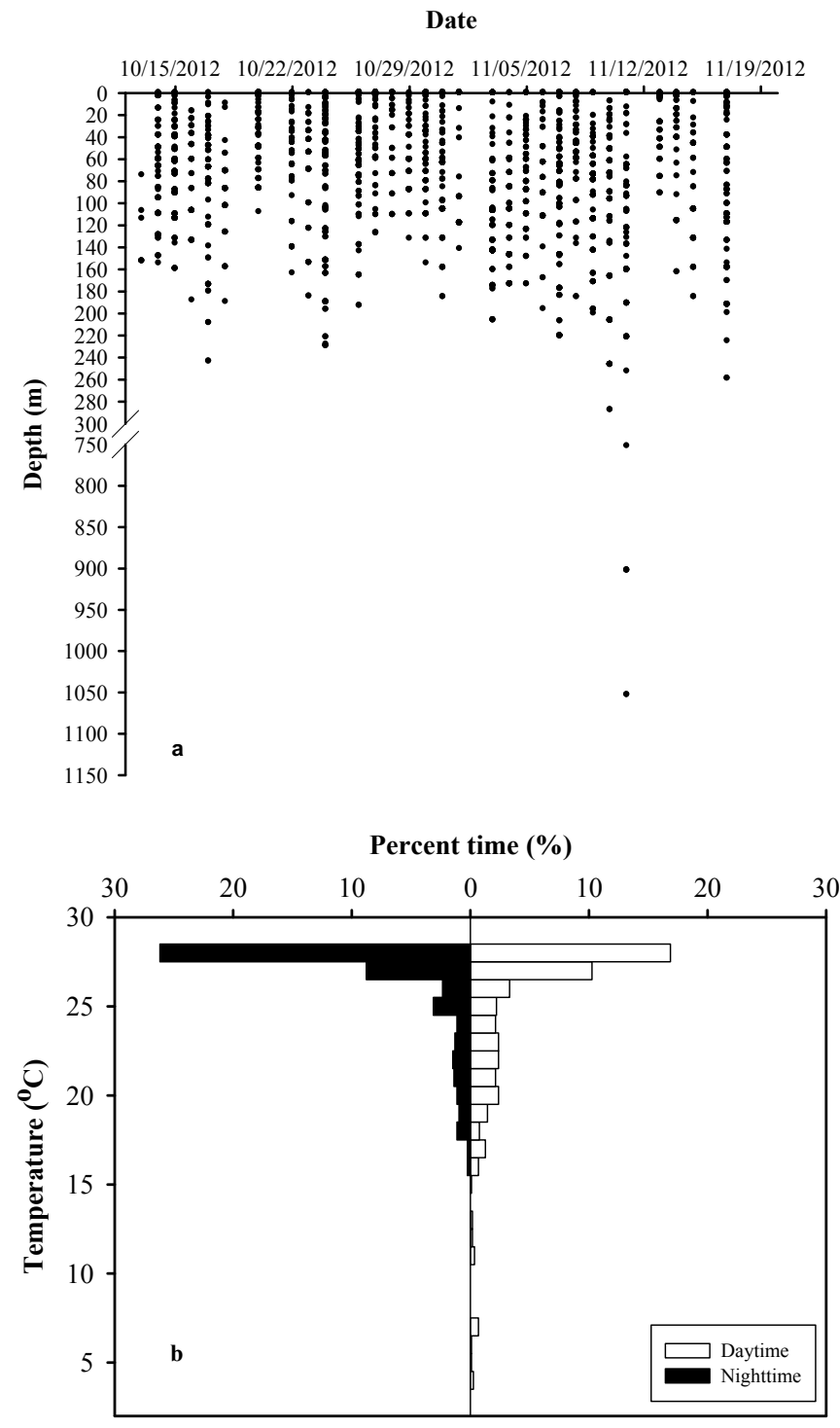

Fig. 8. Vertical movement distribution (a), and percentage of time spent at different temperature (b) for the fish bearing tag I.

PSATs remain attached are not well understood. Possible causes of that have been identified include dart shedding, tissue rejection (Wilson et al., 2005); and failures of the tethers and nose cone pin, faulty battery (Hays et al., 2007), and excessive tissue bleeding or infection (Hoolihan et al., 2011). The stainless steel darts were embedded in the dorsal musculature 
Table 3. Cumulative percentage of deviates of the ambient temperature of yellowfin tuna and daily mean sea surface temperature (SST) which was calculated following Nielsen et al. (2006) and is analogous to Brill et al. (1993).

\begin{tabular}{llllllllll}
\hline Tags & \multicolumn{7}{c}{$\Delta$ SST $\left({ }^{\circ} \mathrm{C}\right)$} \\
\cline { 2 - 9 } & 0 & -1 & -2 & -3 & -4 & -5 & -6 & -7 \\
\hline $\mathrm{D}$ & 70.6 & 81.2 & 86.8 & 88.1 & 90.5 & 93.1 & 94.4 & 96.9 \\
$\mathrm{~F}$ & 49.3 & 70.4 & 74.1 & 82.3 & 86.7 & 89.4 & 92.8 & 95.2 & 99.1 \\
$\mathrm{I}$ & 57.6 & 67.6 & 73.0 & 76.0 & 80.4 & 84.3 & 87.8 & 91.0 & 94.0 \\
\hline
\end{tabular}

and the tag dart head were not passed through the pterygiophores of the dorsal fin. Possible causes of the tag release have been identified as tissue rejection. All of the 11 tags deployed in the present study were released before the programmed pop off dates (180 days). The tags releases were caused by the death of four of the 11 tagged fish because tags are automatically released when they remain in the same water layer for 3 days. These deaths may have been triggered by an injury sustained since the fish were caught but was not detected during tagging or caused by tagging. For example, the fish bearing tag A only provided the data when it went into the waters, then it remained in the same water layer for 3 days. We thus decided the fish died soon after the release. The fish bearing tag $\mathrm{C}$ died at a depth of approximately $904 \mathrm{~m}$ on day 4 after release. The fish bearing tag I exhibited deep dive to a depth of $1000 \mathrm{~m}$ on day 31, which might be due to predator's attack. The fish died on day 38 and sank to $1900 \mathrm{~m}$ in depth, and the tag was pup-off and floated to the surface.

\subsection{Vertical movements}

Seven tagged yellowfin tuna primarily stayed in the mixed layer and spent $97.6 \%$ of time above a depth of $200 \mathrm{~m}$ (Fig. 3), and spent $71 \%$ of their time in waters $<50 \mathrm{~m}$ with temperature of $26-28^{\circ} \mathrm{C}$ (Fig. 4, Tab. 4). This result suggested that this species has a preference for this water layer as its habitat. Similarly, most studies indicated that yellowfin tuna generally spent most of their time either in the mixed layer or at the top of the thermocline (Carey and Olson, 1982; Block et al., 1997; Brill et al., 1999; Weng et al., 2009). Indeed, long-term data recorded by archival tags have demonstrated that yellowfin tuna stay between the mixed layer and thermocline over long periods (Dagorn et al., 2006; Schaefer et al., 2007), which aligns with the results of this study.

Schaefer et al. (2007) noted that the mean vertical movement depth of yellowfin tuna in the EPO at night was less than that occurring during the day. Similar results were reported by Weng et al. (2013) on juvenile yellowfin tuna in the waters off southwestern Taiwan. However, in the present study, the vertical movement depth of adult yellowfin tuna was counter to that of juvenile fish in this area and those in other waters. Many juvenile yellowfin tuna and skipjack gathered near subsurface FADs from September to November in southwestern Taiwan. In addition, the behaviour of adult yellowfin tuna may be altered by chasing prey, and subsurface FADs. Previous study (Weng et al., 2013) was based on the observation of juvenile yellowfin tuna's fine-scale movement behaviour around one subsurface FAD, while the present study covered wider range waters where multiple FADs were found in the study area. The subsurface anchored FADs have a significant effect on vertical behaviour of tunas as well as potential influence on horizontal movement. Holland et al. (1990) argued that vertical movement was primarily restricted to within the mixed layer, with occasional brief dives below the thermocline when yellowfin tuna approach islands.

Josse et al. (1998) found that the deep-sea scattering layer (DSL) in their studied waters was at approximately $100 \mathrm{~m}$ and that yellowfin tuna vertical movements occurred in the DSL. Ménard et al. (2000) indicated that, because yellowfin tuna feed a variety of organisms, such as teleosts and squids, they must have extensive vertical movement, which may be related to searching for food. Marchal et al. (1993) reported that the feeding patterns of yellowfin tuna during the daytime and at nighttime were consistent with the distribution of DSL organisms. A study on the relationship between predator and food further clarified this relationship (Josse et al., 1998). Generally, the DSL occurs at a depth of $40-100 \mathrm{~m}$ in the study area, although this varies slightly by season. Moreover, the DSL in nighttime is apparently shallower than that in the daytime (Weng et al., 2013).

In the present study, the vertical movement of adult yellowfin tuna is primarily to the 100-m water column, both during the daytime and at nighttime (Fig. 3), which is consistent with the depth of the mixed layer and the main distribution of the DSL (Weng et al., 2013). Therefore, the diurnal change in DSL depth is suggested to be one of the major factors influencing the vertical movement of yellowfin tuna. There are several subsurface FADs in the waters off southwestern Taiwan that provide enhanced feeding opportunities (Hunter and Mitchell, 1967; Itano and Buckley, 1987; Holland et al., 2003). In addition, given the proximity of Siaoliuqiu Island, the quantity of food organisms in the waters near the island may be greater than that in offshore waters (Murphy and Shomura, 1972). Yellowfin tuna are thus motivated to stay in the same waters for several months to search food (Longhurst, 1967). Spawning of yellowfin tuna in the western Pacific Ocean occurred all year around with a peak season from February to June (Sun et al., 2005), and extensively spawning was found in Philippines waters (Vera and Hipolito, 2006). However, the spawning behaviour of yellowfin tuna cannot be validated from the tagging results derived from this study.

\subsection{Deep diving behaviour}

The fish with tags D, F, and I displayed deep diving behaviour, with maximum vertical movement depths ranging from 240 to $1100 \mathrm{~m}$ and water temperatures ranging from 13 to 
$4.4^{\circ} \mathrm{C}$ according to the pop-up tags and from 12.6 to $4.4^{\circ} \mathrm{C}$ according to the CTD (Fig. 9a-c, Tab. 4). The stomach content of yellowfin tuna is dominated by adult Oplophorus gracilirostris, a mesopelagic shrimp that resides below $300 \mathrm{~m}$ during the day (Holland et al., 2003). It is difficult in identifying the purpose of deep diving behaviour. Foraging, predator avoidance or anti parasite are all possible purposes. Although this deep diving behaviour is rare suggesting that this is not typical foraging behaviour, the quite slow rate of descent and the prolonged time at depth do not suggest predator avoidance (Dagorn et al., 2006). Such behaviour is probably signified by bounce dives at higher speeds such as over 6 body lengths per second (Holland et al., 1990). Brill et al. (2005) demonstrated that fish with deep diving abilities have enhanced feeding success rates because many food organisms have diurnal vertical movement behaviour and more food can be obtained by vertical movements during deep dives (see also Hays, 2003). With greater thermoregulatory and oxygencarrying capacities, bigeye tuna utilize waters with low temperature and oxygen levels (Holland et al., 1992), often reaching depths of $500 \mathrm{~m}$ multiple times per day where the temperature minimum is $5-10^{\circ} \mathrm{C}$ and the oxygen level is $<3 \mathrm{mg}^{-1}$ (Musyl et al., 2003), and bigeye tuna less than $5^{\circ} \mathrm{C}$, $1.5 \mathrm{mg}^{-1}$ (Brill et al., 2005). For yellowfin tuna, surviving these environmental extremes is aided by their central transverse heat exchange capacities, which save energy and keep their body temperatures higher than the ambient environment (Graham, 1975; Dizon and Brill, 1979). Because increased thermal inertia reduces the body cooling rate, these fish can successfully predate on food or avoid predators below the thermocline (Neill et al., 1976). In other words, yellowfin tuna probably optimize their searching strategy by adjusting the vertical extent of movements with their thermal niche (Sims et al., 2008). However, although yellowfin tuna are extensively distributed and the large individuals are better adapted of cooler water (Collette and Nauen, 1983), they may reduce their energy output due to the temperature changes (Korsmeyer et al., 1997; Brill et al., 1999). For example, when the water temperature drops from 25 to $10^{\circ} \mathrm{C}$, the heart energy output is reduced by $72 \%$ (Blank et al., 2002). Overall, water temperatures below $15^{\circ} \mathrm{C}$ may hamper the yellowfin tuna's ability of to flee predators or chase prey (Weng et al., 2009). When the temperature is below $8^{\circ} \mathrm{C}$, the vertical movement of yellowfin tuna is almost completely inhibited (Brill et al., 1999).

Oxygen content may be one of the key factors influencing the movement behaviour of yellowfin tuna. Bushnell et al. (1990) reported that fish will increase mouth gaping behaviour, increase ventilation volume and decrease heart rate when oxygen concentrations are $<5.1 \mathrm{mgl}^{-1}$. Other field studies have shown that yellowfin tuna tend to avoid waters where the oxygen concentration is $<5.7 \mathrm{mg}^{-1}$ (Cayre and Marsac, 1993). Similarly, Brill et al. (1999) reported that the vertical movement of yellowfin tuna is inhibited when the oxygen content is $<3.5 \mathrm{mg} \mathrm{l}^{-1}$. In the present study, the yellowfin tuna movements mainly occurred at a depth of $50 \mathrm{~m}(43.6 \%)$ where the oxygen content was observed to be 6.2-7.3 $\mathrm{mg}^{-1}$ (Tab. 4). The oxygen content was also found to decrease to $4.4 \mathrm{mg}^{-1}$ at a depth of $300 \mathrm{~m}$ and to $<3.0 \mathrm{mg} \mathrm{l}^{-1}$ at a depth of $1000 \mathrm{~m}$. At $1000 \mathrm{~m}$, the temperature was only $4^{\circ} \mathrm{C}$, with the corresponding oxygen content being insufficient for yellowfin tuna (Tab. 4). Therefore, yellowfin tuna typically avoid entering this water
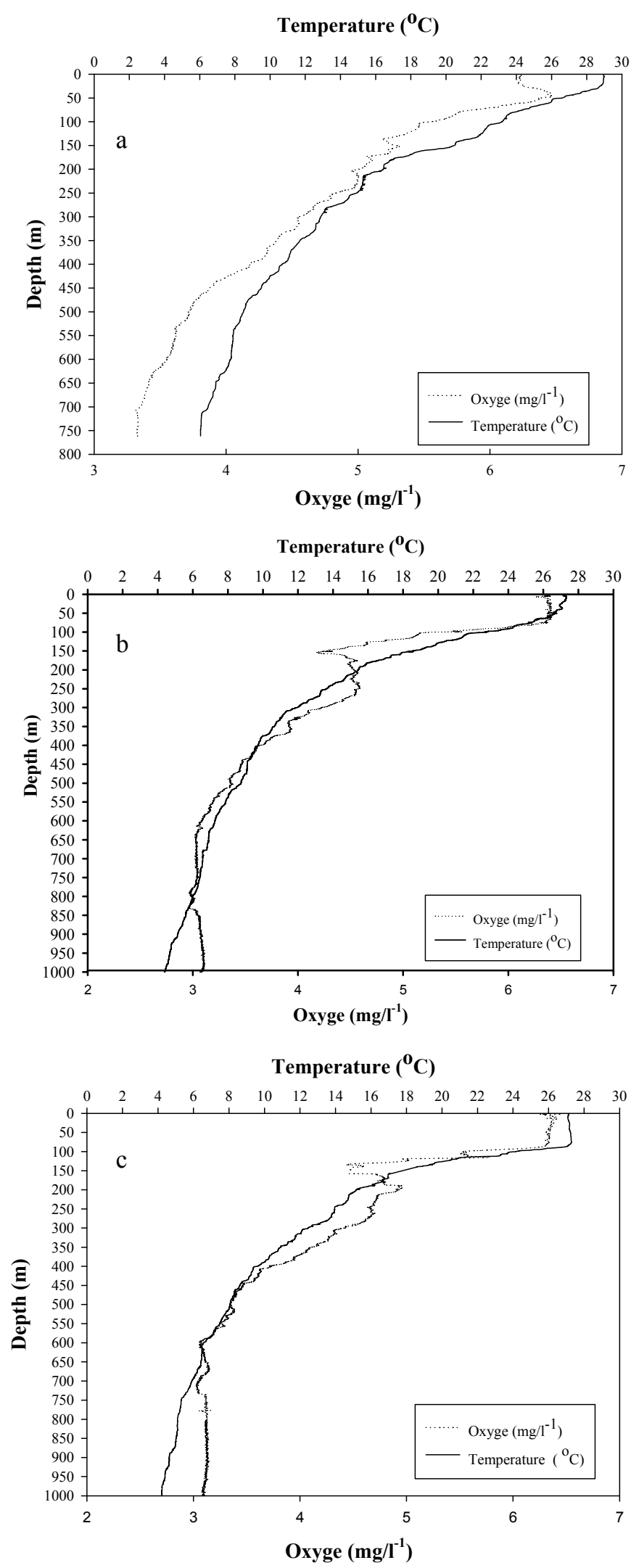

Fig. 9. Vertical profile of waters temperature, depth and oxygen recorded using CTD at the location where the tagged fish were released $\left(22^{\circ} 12^{\prime} \mathrm{N}\right.$; 119 36.2' E). (a) August 2012, (b) May 2013, and (c) November 2013. 
Table 4. Vertical profile of waters temperature, depth and oxygen recorded using CTD in the same area as the tagged fish were released $\left(22^{\circ} 12^{\prime} \mathrm{N} ; 119^{\circ} 36.2^{\prime} \mathrm{E}\right)$ from August 2012 to November 2013.

\begin{tabular}{|c|c|c|c|c|c|c|}
\hline \multirow[t]{2}{*}{ Depth (m) } & \multicolumn{6}{|c|}{ Date } \\
\hline & Temp. $\left({ }^{\circ} \mathrm{C}\right)$ & $\mathrm{O}_{2}\left(\mathrm{mg} \mathrm{l}^{-1}\right)$ & Temp. $\left({ }^{\circ} \mathrm{C}\right)$ & $\mathrm{O}_{2}\left(\mathrm{mg} \mathrm{l}^{-1}\right)$ & Temp. $\left({ }^{\circ} \mathrm{C}\right)$ & $\mathrm{O}_{2}\left(\mathrm{mg} \mathrm{l}^{-1}\right)$ \\
\hline 0 & 29 & 6.2 & 27.1 & 6.4 & 27.2 & 6.4 \\
\hline 50 & 26.7 & 6.4 & 27.2 & 6.3 & 26.8 & 6.4 \\
\hline 100 & 23.3 & 5.6 & 24.1 & 5.5 & 22.7 & 4.9 \\
\hline 400 & 10.7 & 4.2 & 9.6 & 3.7 & 9.7 & 3.6 \\
\hline 500 & 8.5 & 3.7 & 8.1 & 3.3 & 8.7 & 3.4 \\
\hline 600 & 7.6 & 3.6 & 6.6 & 3.1 & 7.2 & 3.1 \\
\hline 700 & 6.5 & 3.3 & 5.9 & 3.0 & 6.6 & 3.0 \\
\hline 1000 & & & 4.2 & 3.1 & 4.4 & 3.1 \\
\hline
\end{tabular}

column and the associated deep diving behaviour, especially below $1000 \mathrm{~m}$ (Fig. 8a and b); it was likely that they were avoiding predators such as marlins, sharks and dolphins.

\subsection{Horizontal movements}

Nakagome (1978) indicated that the optimal temperature for yellowfin tuna ranges from 20 to $29^{\circ} \mathrm{C}$. Weng et al. (2009) found that yellowfin tuna stayed in waters warmer than $22^{\circ} \mathrm{C}$ for $90.7 \pm 0.2 \%$ of their time during the nighttime, compared to $64.7 \pm 0.2 \%$ during the daytime. In the present study, the tagging season was from October to November. According to NOAA satellite data, the SST surrounding Taiwan ranges from 26 to $28^{\circ} \mathrm{C}$ during that period and decreases to approximately $24^{\circ} \mathrm{C}$ in the northern waters in November (Fig. 5a-c). Seven of the tagged yellowfin tuna remained mainly $(71 \%)$ in waters with temperatures of $26-28^{\circ} \mathrm{C}$ (Fig. 4), suggesting a preference for these water temperatures.

Hilborn and Sibert (1988) demonstrated that the travelled distance of tagged yellowfin tuna was primarily within $200 \mathrm{NM}$, although a few fish moved farther (Sibert and Hampton, 2003). Itano and Williams (1992) found that the movement distance of yellowfin tuna in the Western Pacific was limited and Sibert and Hampton (2003) made similar conclusions for yellowfin tuna in the Western and Central Pacific Ocean. In the present study, the 21 and 38 days of data for the yellowfin tuna bearing tags D and I, respectively, showed maximum horizontal movement ranges of approximately $75 \mathrm{NM}$ from Taiwan (Fig. 5a and c). However, the 37-day movement data for the fish bearing tag F revealed that the fish had moved towards the South China Sea, with a pop-up endpoint position of approximately $190 \mathrm{NM}$ from Taiwan $\left(21^{\circ} 51^{\prime} \mathrm{N} ; 117^{\circ} 16.2^{\prime} \mathrm{E}\right)$. Three yellowfin tuna moved close to Siaoliuqiu Island $(<30 \mathrm{NM})$; however, the island effects on horizontal movement could not be identified in this study. Limited movement of yellowfin tuna may be due to the (quality/ quantity) of prey resources (Wells et al., 2012) and the highly suitable habitat experienced by yellowfin tuna in the waters probably enhances residency and limits their movement (Rooker et al., 2016). It is possible that the fish F did not return to the area where it was tagged during the winter months due to decreased temperature in this area. The water temperature in the South China Sea was approximately $27^{\circ} \mathrm{C}$, which was higher than the waters off southwestern Taiwan (Fig. 5b). This dynamic may be the reason for the overall southwest ward movement of the yellowfin tuna. This area is one of the main fishing areas for Taiwan's coastal and offshore tuna longline fishery, especially in autumn and winter (Shih et al., 2009). Therefore, adult yellowfin tuna might move between the waters off the southwestern coast of Taiwan and the South China Sea as the movement distance is short. Recent tagging data results of yellowfin tuna in the EPO have also not indicated any movement to the Taiwanese waters (Schaefer et al., 2007, 2014). At present, the movement information of yellowfin tuna in the northwest Pacific Ocean remains insufficient because of the small sample size. This situation can be improved through international cooperation in the future.

\subsection{Management and conservation}

Tagging experiments have proven to be useful in evaluating the use of coastal waters to conserve high-movement fish species such as Gadus morhua (Schopka et al., 2010). Because of the problems with traditional fisheries management, researchers have suggested establishing marine-protected areas to ensure the sustainability of fisheries (Hilborn et al., 2004; Game et al., 2010). Because tagging data provide detailed information on the behaviour and habitats of fish, specific fishing gear and methods can be modified over time to manage target species effectively (Brill and Lutcavage, 2001). The present study demonstrated that yellowfin tuna moved within a small range. The tagged fish remained in the waters off southwestern Taiwan for approximately 30 days. This result was similar to the findings of Weng et al. (2013), which documented that juvenile fish remained near FADs for approximately 31 days. An increase in the number of yellowfin tuna caught by tiger net fisheries around the subsurface FADs in southern Taiwan waters has caused concern among local government and environmental groups. Therefore, tiger net fishery has been prohibited since 1999, and any new FAD deployment was not allowed since 2006. The data presented in this study have provided the first information on the movement patterns of adult yellowfin tuna in southwestern Taiwan waters. 
This information can be used as a reference for resource utilization and the management of coastal and offshore subsurface FADs.

\section{Conclusion}

This study indicated that the vertical movement behaviours of adult yellowfin tuna were different from those of juvenile yellowfin tuna. The mean depth of vertical movement of adult fish was greater than that of juvenile fish (Weng et al., 2013) Overall, almost all adult yellowfin tuna in the waters off southwestern Taiwan stayed at a depth of $50 \mathrm{~m}$ for most of the time. In addition, water temperatures and oxygen distributions were found to influence the movement patterns and vertical movement behaviours of adult yellowfin tuna. More adult YFT should be tagged using PSAT in the future to better understand the behaviour of this stock.

Acknowledgements. This study was financially supported by the Council of Agriculture, Executive Yuan, Taiwan, ROC on contracts 100AS-10.2.1-AI-A1. We would like to thank captains J.J. Lee and F.M. Tsay for their assistance during the research period.

\section{References}

Arnold G, Dewar H. Electronic tags in marine fisheries research: a 30year respective, in: Electronic tagging and tracking in marine fisheries, Springer, Netherlands, 2001, pp. 7-64.

Arrizabalaga H, Pereira JG, Royer F, Galuardi B, Goñi N, Artetxe I, Arregi I, Lutcavage M. 2008. Bigeye tuna (Thunnus obesus) vertical movements in the Azores Islands determined with pop-up satellite archival tags. Fish Ocean 17: 74-83.

Bayliff WH. 1984. Migrations of yellowfin and skipjack tuna released in the central portion of the eastern Pacific Ocean, as determined by tagging experiments. Bull Int Am Trop Comm 18: 107.

Blank JM, Morrissette JM, David PS, Block BA. 2002. Effects of temperature, epinephrine and $\mathrm{Ca}^{2+}$ on the hearts of yellowfin tuna (Thunnus albacares). J Exp Biol 205: 1881-1888.

Block BA, Keen JE, Castillo B, Dewar H, Freund EV, Marcinek DJ, Brill RW, Farwell C. 1997. Environmental preferences of yellowfin tuna (Thunnus albacares) at the northern extent of its range. Mar Biol 130: 119-132.

Block B, Dewar H, Carey F. 1998. A new satellite technology for tracking the movements of Atlantic bluefin tuna. Proc Natl Acad Sci USA 95: 9384-9389.

Brill RW, Holts DB, Chang RKC, Sullivan S, Dewar H, Carey FG. 1993. Vertical and horizontal movements of striped marlin (Tetrapturus audax) near the Hawaiian Islands, determined by ultrasonic telemetry, with simultaneous measurement of oceanic currents. Mar Biol 117: 567-574.

Brill R. 1994. A review of temperature and oxygen tolerance studies of tunas pertinent to fisheries oceanography, movement models and stock assessments. Fish Oceanogr 3: 204-216.

Brill RW, Lutcavage M. 2001. Understanding environmental influences on movements and depth distribution of tuna and billfishes can significantly improve population assessments. Am Fish Soc Symp 25: 179-198.

Brill RW, Block BA, Boggs CH, Bigelow KA, Freund EV, Marcinek DJ. 1999. Horizontal movement and depth distribution of large adult yellowfin tuna (Thunnus albacares) near the Hawaiian Island, recorded using ultrasonic telemetry: implications for the physiological ecology pelagic fishes. Mar Biol 133: 395-408.
Brill RW, Bigelow KA, Musyl MK, Fritsches KA, Warrant EJ. 2005. Bigeye tuna (Thunnus obesus) behaviour and physiology and their relevance to stock assessments and fishery biology. ICCAT Coll Vol Sci Pap 57, 142-161.

Bushnell P, Brill R, Bourke R. 1990. Cardiorespiratory responses of skipjack tuna (Katsuwonus pelamis), yellowfin tuna (Thunnus albacares), and bigeye tuna (Thunnus obesus) to acute reductions of ambient oxygen. Can J Zool 68: 1857-1865.

Carey FG, Olson RJ. 1982. Sonic tracking experiments with tunas. International Commission for the Conservation of Atlantic tunas, Madrid. ICCAT Coll Vol Sci Pap 17: 458-466.

Cayre P, Marsac F. 1993. Modelling the yellowfin tuna (Thunnus albacares) vertical distribution using sonic tagging results and local environmental parameters. Aquat Living Res 6: 1-14.

Chiang WC, Musyl MK, Sun CL, Chen SY, Chen WY, Liu DC, Su WC, Yeh SZ, Fu SC, Huang TL. 2011. Vertical and horizontal movements of sailfish (Istiophorus platypterus) near Taiwan determined using pop-up satellite tags. J Exp Mar Biol Ecol 397: 129-135.

Collette BB, Nauen CE. FAO species catalogue. Scombrids of the world. An annotated and illustrated catalogue of tunas, mackerels, bonitos and related species known to date, in: FAO Fish. Synop., 1983, vol. 125 , no. 2, 137 pp.

Dagorn L, Holland KN, Hallier JP, Taqut M, Moreno G, Sancho G, Itano DG, Aumeeruddy R, Girard C, Million J, Fonteneau A. 2006. Deep diving behaviour observed in yellowfin tuna (Thunnus albacares). Aquat Living Res 19: 85-88.

Dizon AE, Brill RW. 1979. Thermoregulation in yellowfin tuna, Thunnus albacares. Physiol Zool 52: 581-593.

Fink BD, Bayliff WH. 1970. Migrations of yellowfin and skipjack tuna in the eastern Pacific Ocean, as determined by tagging experiments, 1952-1964. Bull Int Am Trop Comm 15: 1-227.

Fonteneau A. 1998. Introduction aux problèmes des relations thonsenvironnement dans 1'Atlantique. ICCAT Coll Vol Sci Pap 50: $275-318$.

Game ET, Grantham HS, Hobday AJ. 2010. Pelagic MPAs: the devil you know. Trends Ecol Evol 25: 63-64.

Graham JG. 1975. Heat exchange in the yellowfin tuna, Thunnus albacares, and skipjack tuna, Katsuwonus pelamis, and the adaptive significance of elevated body temperatures. Fish Bull 72: 219-229.

Gunn J, Block B. Advances in acoustic, archival and satellite tagging of tunas, in: B.A. Block, E.D. Stevens (Eds.), Tunas: physiology, ecology and evolution, Academic Press, San Diego, CA, 2001, pp. $167-224$.

Hays GC. 2003. A review of the adaptive significance and ecosystem consequences of zooplankton diel vertical migrations. Hydrobiologia 503: 163-170.

Hays GC, Bradshaw CJA, James MC, Lovell P, Sims DW. 2007. Why do Argos satellite tags deployed on marine animals stop transmitting? J Exp Mar Biol Ecol 349: 52-60.

Hilborn R, Sibert J. 1988. Is international management of tuna necessary? Mar Policy 12: 31-39.

Hilborn R, Stokes TK, Maguire JJ. 2004. When can marine reserves improve fisheries management? Ocean Coast Manag 47: 197-205.

Holland KN, Brill RW, Chang R. 1990. Horizontal and vertical movements of yelowfin tuna and bigeye tuna associated with fish aggregating devices. Fish Bull 88: 493-507.

Holland K, Brill R, Chang R, Sibert J, Fournier D. 1992. Physiological and behavioural thermoregulation in bigeye tuna (Thunnus obesus). Nature 358: 410-412.

Holland K, Grubbs B, Graham D, Itano D, Dagorn L. The biology of FAD-associated tuna: temporal dynamics for association and feeding ecology, in: WP YFT-7, Mooloolaba, Australia, 9-16 July 2003, 2003. 
Hoolihan JP, Luo J, Abascal FJ, Campana SE, De Metrio G, Dewar H, Domier ML, Howey LA, Lutcavage ME, Musyl MK, Neilson JD, Orbesn ES, Prince ED, Rooker JR. 2011. Evaluating post-release behaviour modification in large pelagic fish deployed with pop-up satellite archival tags. ICES J Mar Sci 68: 880-889.

Hunter JR, Mitchell CT. 1967. Association of fishes with flotsam in offshore waters of Central America. US Fish Wildl Serv Fish Bull 66: 13-29.

Itano DG, Buckley TW. Report on the fish aggregating device (FAD) program in American Samoa (1979 to November 1987), Unpublished Rep, Department of Marine and Wildlife Resources, Pago Pago, Am. Samoa, 1987, 49 pp.

Itano DG, Williams PG. Analysis of yellowfin tuna tagging data and related information collected by the skipjack survey and assessment program, Tuna and Billfish Assessment Programme Technical Report 28, South Pacific Commission, 1992.

Itano DG, Holland KN. 2000. Movement and vulnerability of bigeye (Thunnus obesus) and yellowfin tuna (Thunnus albacares) in relation to FADs and natural aggregation points. Aquat Living Resour 13: 213-223.

Josse E, Bach P, Dagorn L. 1998. Simultaneous observations of tuna movements and their prey by sonic tracking and acoustic surveys. Hydrobiologia 371: 61-69.

Kleiber P, Hampton J. 1994. Modeling effects of FADs and islands on movement of skipjack tuna (Katsuwonus pelamis): estimating parameters from tagging data. Can J Fish Aquat Sci 51(12): 26422-26653.

Korsmeyer KE, Lai NC, Shadwick RE, Graham JB. 1997. Heart rate and stroke volume contributions to cardiac output in swimming yellowfin tuna: response to exercise and temperature. J Exp Biol 20: 1975-1986.

Lam CH, Nielsen A, Sibert JR. 2008. Improving light and temperature based geolocation by unscented Kalman filtering. Fish Res 91: 15-25.

Lam CH, Galuardi B, Lutcavage ME. 2014. Movements and oceanographic associations of bigeye tuna (Thunnus obesus) in the Northwest Atlantic. Can J Fish Aquat Sci 71: 1-15.

Lehodey P, Andre JM, Bertignac M, Hampton J, Stoens A, Menkes C, Memery L, Grima N. 1998. Predicting skipjack tuna forage distributions in the equatorial Pacific using a coupled dynamical bio-geochemical model. Fish Oceanogr 7: 317-325.

Longhurst AR. 1967. The pelagic phase of Pleuroncodes planipes Stimpson (Crustacea, Galatheidae) off California. Calif Coop Ocean Fish Investig Rep 11: 142-154.

Marchal E, Gerlotto F, Stequert B. 1993. On the relationship between scattering layer, thermal structure and tuna abundance in the Eastern Atlantic equatorial current system. Oceanol Acta 16: 261-272.

Ménard F, Stéquert B, Rubin A, Herrera M, Marchal E. 2000. Food consumption of tunas in the Equatorial Atlantic: FAD associated versus unassociated schools. Aquat Living Res 13: 233-240.

Murphy GI, Shomura RS. 1972. Pre-exploitation abundance of tunas in the equatorial central Pacific. Fish Bull 70: 875-913.

Musyl MK, Brill R.W, Boggs CH, Curran DS, Kazama TK, Seki MP. 2003. Vertical movements of bigeye tuna (Thunnus obesus) associated with islands, buoys, and seamounts near the main Hawaiian Islands from archival tagging data. Fish Oceanogr 12: 152-169.

Nakagome J. 1978. The study of relation between tuna and oceanography. Bull Jpn Soc Fish Oceanogr 44: 231-234.

Neill WH, Chang RKC, Dizon AE. 1976. Magnitude and ecological implications of thermal inertia in skipjack tuna, Katsuwonus pelamis (Linnaeus). Environ Biol Fish 1: 61-80.
Nielsen A, Bigelow KA, Musyl MK, Sibert JR. 2006. Improving light-based geolocation by including sea surface temperature. Fish Oceanogr 15: 314-325.

Rooker JR, David Wells RJ, Itano DG, Thorrold SR, Lee JM. 2016. Natal origin and population connectivity of bigeye and yellowfin tuna in the Pacific Ocean. Fish Oceanogr 25: 277-291.

Schaefer KM, Fuller DW, Block BA. 2007. Movements, behavior, and habitat utilization of yellowfin tuna (Thunnus albacares) in the northeastern Pacific Ocean, ascertained through archival tag data. Mar Biol 152: 503-525.

Schaefer KM, Fuller DW, Gabriel A. 2014. Movements, behavior, and habitat utilization of yellowfin tuna (Thunnus albacares) in waters surrounding the Revillagigedo island Archipelago biosphere reserve, Mexico. Fish Oceanogr 23: 65-82.

Schopka SA, Solmundsson J, Ragnarsson SA, Thorsteinsson V. 2010. Using tagging experiments to evaluate the potential of closed areas in protecting migratory Atlantic cod (Gadus morhua). ICES J Mar Sci 67: 1024-1035.

Shih NT, Huang L, Cai YH, Ni IH. 2009. Fishing efficiency of the Taiwanese offshore tuna longline fishery. J Fish Soc Taiwan 36: 77-89.

Sibert J, Hampton J. 2003. Mobility of tropical tunas and the implications for fisheries management. Mar Policy 27: 87-95.

Sims DW, Southall EJ, Humphries NE, Hays GC, Bradshaw CJA, Pitchford JW, James A, Ahmed MZ, Brierley AS, Hindell MA, Morritt D, Musyl MK, Righton D, Shepard ELC, Wearmouth VJ, Wilson RP, Witt MJ, Metcalfe JD. 2008. Scaling laws of marine predator search behaviour. Nature 451: 1098-1103.

Sun CL, Wang WR, Yeh S, Reproductive biology of yellowfin tuna in the central and western Pacific Ocean, in: WCPFC-SC1, BI WP-1, 2005.

Turchin P. Quantitative analysis of movement: measuring and modeling population redistribution in animals and plants, Sinauer Associates, Inc., Sunderland, MA, 1998.

Vera CA, Hipolito Z. The Philippines Tuna Industry: a profile. International Collective in Support of Fishworkers, 2006, 72 pp.

Weng KC, Stokesbury MJW, Boustany AM, Seitz AP, Teo SLH, Miller SK, Block BA. 2009. Habitat and behaviour of yellowfin tuna Thunnus albacares in the Gulf of Mexico determined using pop-up satellite archival tags. J Fish Biol 74: 1434-1449.

Weng JS, Hung MK, Lai CC, Wu LJ, Lee MA, Liu KM. 2013. Finescale vertical and horizontal movements of juvenile yellowfin tuna (Thunnus albacares) associated with a subsurface fish aggregating device (FAD) off southwestern Taiwan. J Appl Ichthyol 29: 990-1000.

Weng JS, Lee MA, Liu KM, Hsu MS, Hung MK, Wu LJ. 2015. Feeding ecology of juvenile yellowfin tuna Thunnus albacares from waters southwest of Taiwan inferred from stomach contents and stable isotope analyses. Mar Coast Fish 7: 537-548.

Wells RJD, Rooker JR, Itano DG. 2012. Nursery origin of yellowfin tuna in the Hawaiian Islands. Mar Ecol Prog Ser 461: 187-196.

Western and central pacific fisheries commission tuna fishery yearbook, 2015, 154 pp.

Wilson SG, Lutcavage ME, Brill RW, Genovese MP, Cooper AB, Everly AW. 2005. Movements of bluefin tuna (Thunnus thynnus) in the northwestern Atlantic Ocean recorded by pop-up satellite archival tags. Mar Biol 146: 409-423.

Yuen HS. 1970. Behavior of skipjack tuna, Katsuwonus pelamis, as determined by tracking with ultrasonic devices. J Fish Board Can 27: 2071-2079.

Cite this article as: Weng J-S, Lee M-A, Liu K-M, Huang H-H, Wu L-J. 2017. Habitat and behaviour of adult yellowfin tuna (Thunnus albacares) in the waters off southwestern Taiwan determined by pop-up satellite archival tags. Aquat. Living Resour. 30 : 34 